Article

\title{
Synthesis and Anti-Hyperlipidemic Evaluation of $N$-(Benzoylphenyl)-5-fluoro-1H-indole-2-carboxamide Derivatives in Triton WR-1339-Induced Hyperlipidemic Rats
}

Ghassan Shattat ${ }^{1, *}$, Rania Al-Qirim ${ }^{2}$, Yusuf Al-Hiari ${ }^{2}$, Ghassan Abu Sheikha ${ }^{1}$, Tariq Al-Qirim ${ }^{1}$, Waseem El-Huneidi ${ }^{1}$ and Moyad Shahwan ${ }^{1}$

1 Faculty of Pharmacy, Al-Zaytoonah Private University, Amman, Jordan

2 Faculty of Pharmacy, University of Jordan, Amman, Jordan

* Author to whom correspondence should be addressed; E-Mail: gassan10@yahoo.com;

Tel.: 0096279648 8599; Fax: 0096264291432.

Received: 23 June 2010; in revised form: 18 August 2010 / Accepted: 20 August 2010 /

Published: 26 August 2010

Abstract: The lipid-lowering activity of a series of novel $\mathrm{N}$-(benzoylphenyl)-5-fluoro- $1 \mathrm{H}$ indole-2-carboxamide derivatives has been studied in Triton WR-1339-induced hyperlipidemia in rats. The test animals were divided into four groups: control, hyperlipidemic, compound + 4\% DMSO [C1: $N$-(2-benzoylphenyl)-5-fluoro- $1 \mathrm{H}$-indole-2carboxamide (1), C2: $\mathrm{N}$-(3-benzoylphenyl)-5-fluoro-1H-indole-2-carboxamide (2), C3: $\mathrm{N}$ (4-benzoylphenyl)-5-fluoro-1H-indole-2-carboxamide (3)]-treated and bezafibrate (BF)treated. At a dose of $15 \mathrm{mg} / \mathrm{Kg}$ body weight, compounds 2, 3 and BF significantly reduced elevated plasma triglycerodes levels after $12 \mathrm{~h}$. Moreover, high density lipoproteincholesterol levels were significantly increased in all treated groups after $12 \mathrm{~h}$ compared to the hyperlipidemic control group, except for $\mathbf{C} 1$ which was inactive. In sum, it may be stated that the results of the present study demonstrated new properties of some $\mathrm{N}$ (benzoylphenyl)-5-fluoro-1H-indole-2-carboxamide derivatives as potent lipid lowering agents and these beneficial activities may contribute to their cardioprotective and antiatherosclerotic role.

Keywords: Triton WR-1339-induced hyperlipidemic rats; $\mathrm{N}$-(benzoylphenyl)-5-fluoro$1 \mathrm{H}$-indole-2-carboxamides; high-density lipoprotein-cholesterol; triglycerides; hypolipidemic activity 


\section{Introduction}

Hyperlipidemia is defined as an elevation of lipids in plasma [1]. Several studies have showed that an intimate correlation exists between coronary heart diseases and hyperlipidemia [2,3], consequently a rational approach to the treatment and prevention of coronary heart diseases could be by decreasing any elevated levels of lipids in plasma [4]. For that purpose, many studies have been conducted to evaluate the potential hypolipidemic effects of synthetic and naturally occurring compounds.

Triton WR-1339-induced hyperlipidemic rats are a globally accepted model used to evaluate potential hypolipidemic drugs [5]. Triton WR-1339 is a nonionic detergent that prevents catabolism of triacylglycerol-rich lipoproteins by lipo-protein lipase and is commonly used for in vivo determination of triacylglycerol production, and very low density lipoprotein (VLDL) secretion or clearance rate $[6,7]$.

Treatment with fibrates, a widely used class of lipid-modifying agents, results in a significant decrease in plasma triglycerides (79\%) and is usually associated with a decrease in low density lipoprotein (LDL), cholesterol (11\%), and an increase in high density lipoprotein (HDL)-cholesterol concentrations (27\%) [8]. The major pharmacological mechanism of fibrates, including bezafibrate, is by the induction of lipoprotein lipase and reduction of apolipoprotein C-III synthesis leading to increased hydrolysis of triglycerides (TG) [9,10].

Some indole derivatives are well-known for their diverse pharmacological effects including a hypolipidemic effect [11-15]. Although studies have shown the potential role for indole-2carboxamide derivatives as anti-allergics [16], and antioxidants [17,18],to the best of our knowledge $\mathrm{N}$-(benzoylphenyl)-5-fluoro- $1 \mathrm{H}$-indole-2-carboxamide derivatives have not been investigated as potential lipid-lowering agents. In the present study, we aimed to synthesize a new series of ethyl-5fluoro- $1 H$-indole-2-carboxamide derivatives and to investigate their hypolipidemic activity using Triton WR-1339 induced hyperlipidemic rats as a model.

\section{Results and Discussion}

\subsection{Chemical Studies}

A novel series of $N$-(benzoylphenyl)-5-fluoro-1H-indole-2-carboxamides 1-5 (Scheme 1) were prepared in the course of this work. The target compounds were synthesized in one step by the coupling reaction between ethyl-5-fluoro-1H-indole-2-carboxylate (6) and an excess of the corresponding aminobenzophenones 7-11 in the presence of sodium ethoxide in DMF or DMSO at 150-190 ${ }^{\circ} \mathrm{C}$, as shown in the Scheme. The reaction mixtures were purified using column chromatography to afford the desired compounds. These reaction conditions gave the targets in relatively low yields $(6 \%-37 \%)$. The harsh reaction conditions $\left(150-190{ }^{\circ} \mathrm{C}\right)$ and the chromatographic separation led to the decomposition and loss of appreciable amounts of the targets. Although the yields were low, enough pure amounts of each compound could be collected for the pharmacological evaluation. 
Scheme 1. Synthesis of 5-fluoro- $1 \mathrm{H}$-indole-2-carboxamides from un-substituted and substituted aminobenzophenones.

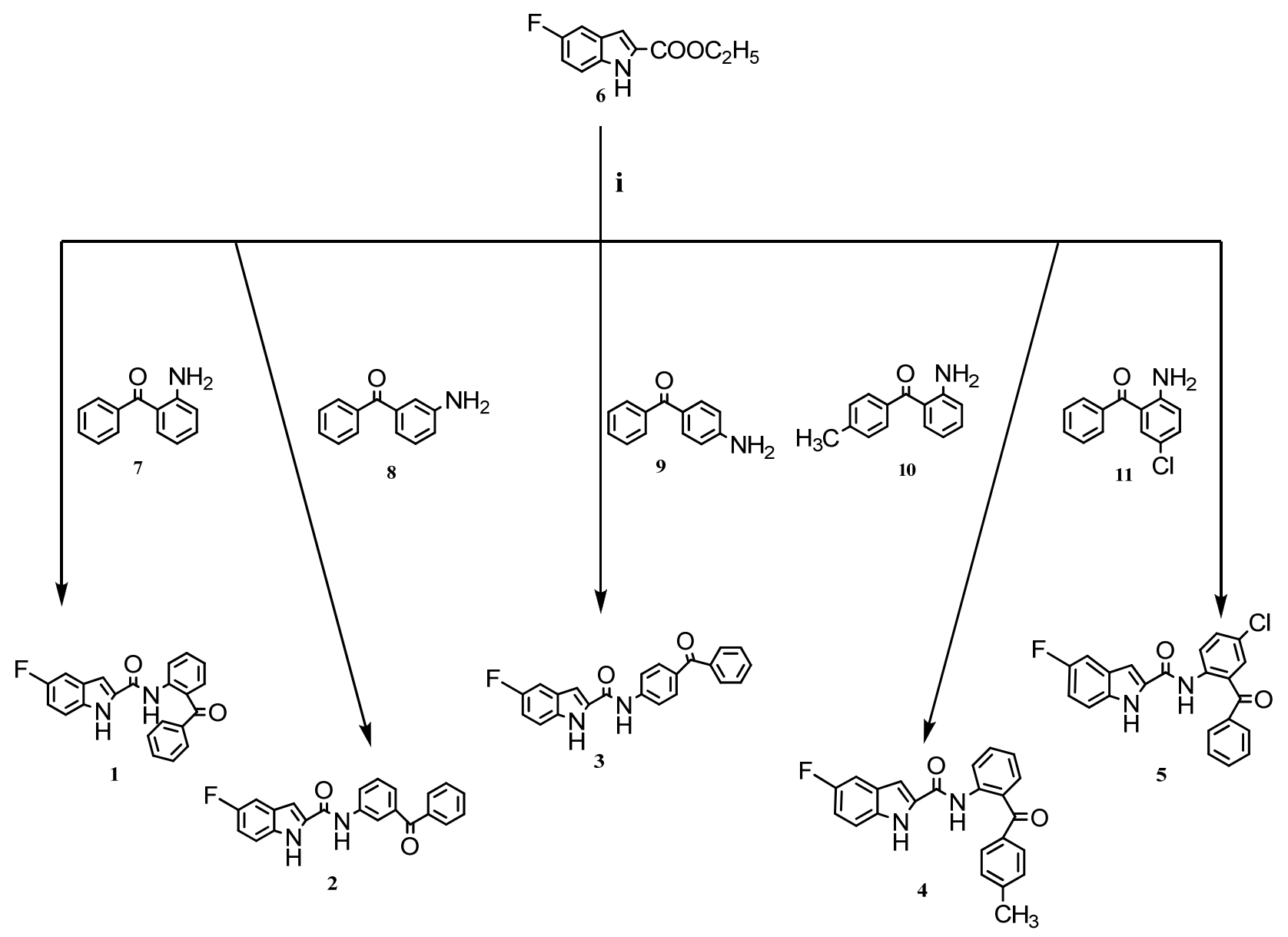

Reagents and Conditions: i) sodium ethoxide, DMF or DMSO, $150-190^{\circ} \mathrm{C}$.

\subsection{Pharmacological Studies}

\subsubsection{Induction of Hyperlipidemia by Triton WR-1339}

The levels of plasma total cholesterol (TC), triglyceride (TG), high-density lipoprotein cholesterol (HDL-C) and low-density lipoprotein cholesterol (LDL-C) levels of all groups treated for $12 \mathrm{~h}$ after Triton administration are shown in Figure 1. In comparison with the normal control group (CG), Triton WR-1339 caused a significant increase in cholesterol and triglyceride plasma concentrations measured $12 \mathrm{~h}$ after Triton injection. After $12 \mathrm{~h}$, the plasma total cholesterol was increased by (32\%) and triglycerides by more than eight times.

Triton WR-1339 caused a significant decrease in HDL cholesterol levels in the hyperlipidemic control (HG), at $12 \mathrm{~h}$ after Triton administration, in comparison with the CG. In fact, the decrease of plasma total cholesterol concentration in the $\mathrm{HG}$ was $28 \%$ after $12 \mathrm{~h}$ as compared to the CG. When the HG group was compared with CG, we observed that after $12 \mathrm{~h}$ from Triton injection (Figure 1), LDL cholesterol increased by (208\%) 
Figure 1. Effect of Triton-WR1339 on lipid profile after $12 \mathrm{~h}$.

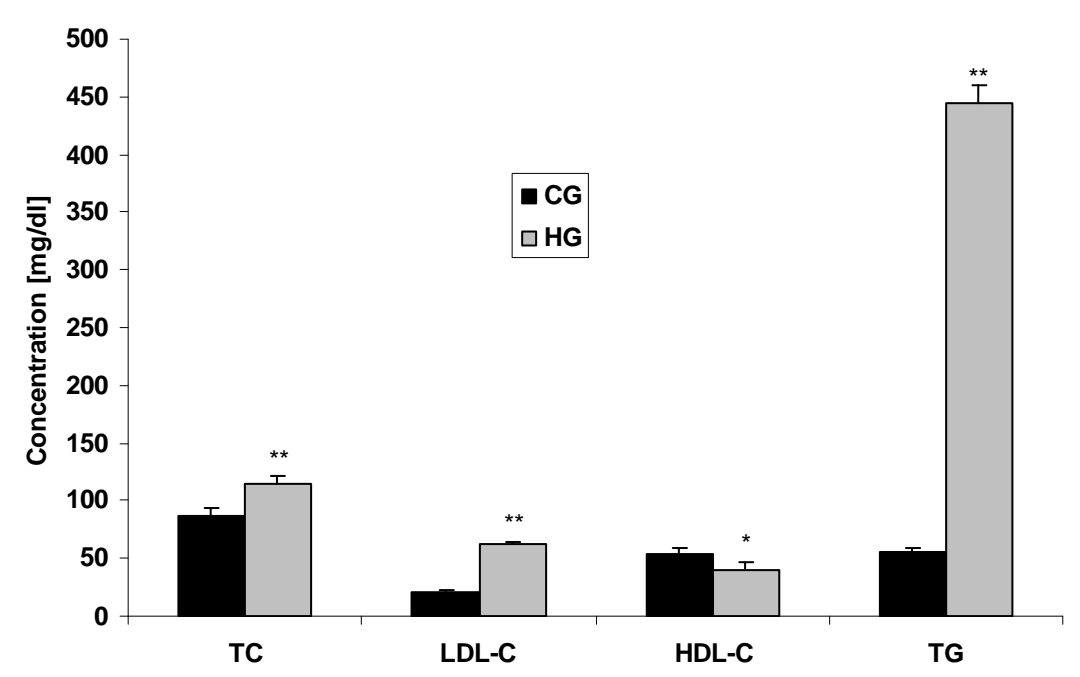

Values are means \pm SEM from eight animals in each group. CG: control group; HG: hyperlipidemic control group; TC: total cholesterol; TG: triglyceride; HDL-C: high-density lipoprotein cholesterol; LDL-C: low density lipoprotein cholesterol. HG is compared to CG. ${ }^{*} p<0.001,{ }^{* *} p<0.0001$.

\subsubsection{Effect of Compounds 1, 2, 3 and Bezafibrate on Rat Plasma Lipid Profile}

The plasma total cholesterol (TC), triglyceride (TG), high-density lipoprotein (HDL-C) and lowdensity lipoprotein (LDL-C) levels of bezafibrate (BF) and compound 1, 2 and 3-treated rats $12 \mathrm{~h}$ after Triton administration are shown in Table 1. Importantly, the elevated plasma TG levels produced by Triton WR-1339 administration were significantly suppressed by BF (79\%), compound 2 (90\%) and compound $3(83 \%)$ after $12 \mathrm{~h}$ with respect to the hyperlipidemic control HG. No significant difference in TG level was observed with compound $\mathbf{1}$, compared to HG-treated rats.

Table 1. Effect of the novel C1, C2, C3 and bezafibrate on plasma lipid levels in Triton WR-1339-induced hyperlipemic rats after $12 \mathrm{~h}$.

\begin{tabular}{lcccc}
\hline Lipid profile & TC (mg/dL) & TG (mg/dL) & HDL-C(mg/dL) & LDL-C (mg/dL) \\
\hline CG & $86.2 \pm 7.2$ & $55.2 \pm 4.5$ & $54.6 \pm 4.1$ & $20.5 \pm 1.9$ \\
HG & $114.2 \pm 6.6$ & $445.0 \pm 14.5$ & $39.5 \pm 6.7$ & $63.2 \pm 1.6$ \\
C 1 & $134.3 \pm 12.2$ & $533.2 \pm 16.3$ & $42.2 \pm 5.7$ & $65.8 \pm 1.3$ \\
C 2 & $124.0 \pm 4.9$ & $46.0 \pm 5.4^{\mathrm{b}}$ & $73.6 \pm 2.3^{\mathrm{b}}$ & $41.2 \pm 2.6^{\mathrm{b}}$ \\
C 3 & $114.0 \pm 0.98$ & $75.3 \pm 7.0^{\mathrm{b}}$ & $60.5 \pm 10.3^{\mathrm{a}}$ & $38.5 \pm 2.3^{\mathrm{b}}$ \\
BF & $125.3 \pm 4.0$ & $95.6 \pm 5.0^{\mathrm{b}}$ & $50.2 \pm 3.7^{\mathrm{a}}$ & $56.0 \pm 3.1$ \\
\hline
\end{tabular}

Values are means \pm SEM from eight animals in each group. CG: normal control group; HG: hyperlipidemic $+4 \%$ DMSO control group; $\mathrm{C} 1$ : compound $1+4 \%$ DMSO; 2 : compound $2+4 \%$ DMSO; C3: compound $3+4 \%$ DMSO; BF: bezafibrate + 4\% DMSO; TC: total cholesterol; TG: triglyceride; HDL-C: high-density lipoprotein cholesterol; LDL-C: low-density lipoprotein cholesterol. C1, C2, C3 and BF are compared with HG. ${ }^{\mathrm{a}} \mathrm{p}<0.01,{ }^{\mathrm{b}} \mathrm{p}<0.0001$. 
HDL-cholesterol levels were significantly increased $12 \mathrm{~h}$ after Triton administration $(+86 \%)$ in the compound 2 and $(+53 \%$ and $27 \%)$ in compound 3 and BF-treated animals, respectively, compared to HG (Table 1). In contrast there was no significant change in TG levels after $12 \mathrm{~h}$ with compound $\mathbf{1}$ with respect to hyperlipidemic control HG.

With the exception of compound 1 and BF, all treated groups showed an obvious and significant reduction in plasma LDL-C levels after $12 \mathrm{~h}$ (Table 1). In fact, it was found that LDL-C levels were reduced by $35 \%$ and $39 \%$ after $12 \mathrm{~h}$ by compound 2 and compound 3, respectively, compared to HGtreated rats. After $12 \mathrm{~h}$ of treatment, no significant differences in plasma total cholesterol levels between any treated groups (BF, compounds 1, 2 and 3) were observed in comparison to HG-treated rats (Table 1). In this study, compound 4 and 5 were not biologically tested because they are derivatives of compound 2 which already revealed inactive

The results of this study demonstrated the potential hypolipidemic effect of the tested 5-fluoro- $1 \mathrm{H}$ indole-2-carboxamide derivatives in Triton WR-1339 induced hyperlipidemic rats. Compounds 2 and 3 significantly reduced serum TG and increased serum HDL. These observations could be explained by understanding the mechanism through which Triton WR-1339 induces hyperlipidemia in adults rats after parenteral administration. The maximum plasma total cholesterol and triglyceride levels were reached at $20 \mathrm{~h}$ followed by a decline to normal values $[19,20]$. In the course of this study, the same model gave a similar pattern of lipid profile changes $12 \mathrm{~h}$ after Triton WR-1339 administration (Figure 1). In fact, triglyceride and cholesterol levels started to increase after 7 hours and reach the peak in $20 \mathrm{~h}$, followed by a decline in triglyceride and cholesterol levels.

Clearly, our results showed that both compounds 2 and 3 at a dose of $15 \mathrm{mg} / \mathrm{kg}$ body weight were able to significantly decrease serum triglycerides levels. The large decrease in plasma HDL-C levels due to Triton WR-1339 injection results mostly from a progressive displacement of the apo A-1 protein from the HDL surface, without loss of lipid [21]. Mean while the large increase in plasma TG levels due to Triton administration results mostly from an increase of very low-density lipoprotein (VLDL) secretion by the liver accompanied by strong reduction of VLDL and LDL catabolism [22].

Thus, since the proportion of triglyceride in VLDL is many times higher than cholesterol, it is not surprising that the hypolipidemic activity of compounds $\mathbf{2}$ and $\mathbf{3}$ was significantly higher for triglycerides than for cholesterol. This result suggests that our compounds are able to restore, at least partially, catabolism of B-lipoproteins as hypothesized by many studies with other lipid-lowering agents [23,24].

In addition, both compounds 2 and 3 increased HDL levels, which are known for their preventive role against atherogenesis. HDL plays an important role in facilitating the mobilization of triglycerides and cholesterol from plasma to liver where it undergoes catabolism and then eliminated in the form of bile acids [25,26].

Promisingly, compounds 2 and 3 at a dose of $15 \mathrm{mg} / \mathrm{kg}$ body weight $12 \mathrm{~h}$ after Triton injection is more significant than the reduction induced by bezafibrate at a dose of $100 \mathrm{mg} / \mathrm{kg}$ body weight, which in this study has been used as standard reference hypolipidemic drug. Furthermore, total cholesterol levels were not significantly changed which agrees with the mechanism of action of fibrates in that their total cholesterol-lowering activity is not strongly marked, but the triglycerides decreasing effect of them is very impressive especially by stimulation of the gene expression of lipoprotein lipase [27]. 


\section{Experimental}

\subsection{General}

The reaction mixtures were purified by column chromatography to afford the desired compounds. Melting points were measured using a Gallenkamp melting point apparatus and are uncorrected. ${ }^{1} \mathrm{H}$ NMR and ${ }^{13} \mathrm{C}-\mathrm{NMR}$ spectra were collected on a Varian Oxford NMR300 spectrometer. The samples were dissolved in $\mathrm{CDCl}_{3}$ at a concentration of $0.3-0.7 \mathrm{wt}$ \% $\%$. High-resolution mass spectra (HRMS) were measured in positive ion mode using electrospray ion trap (ESI) technique by collision-induced dissociation on a Bruker Apex-4 (Tesla) instrument (Bremen, Germany). The samples were dissolved in acetonitrile, diluted in spray solution (methanol/water $1: 1 \mathrm{v} / \mathrm{v}+0.1$ formic acid) and infused using a syringe pump with a flow rate of $2 \mu \mathrm{L} / \mathrm{min}$. external calibration was conducted using the arginine cluster in a mass range $\mathrm{m} / \mathrm{z}$ 175-871. Infrared spectra were recorded using a Shimadzu IRAffinity-1 spectrophotometer. The samples were dissolved in $\mathrm{CHCl}_{3}$ and analyzed as thin solid films using $\mathrm{NaCl}$ plates. Analytical thin layer chromatography (TLC) was carried out using pre-coated aluminum plates and visualized by UV light $(\lambda=254$ and/or $360 \mathrm{~nm})$. Elemental analysis was performed using EuroVector elemental analyzer (Milan, Italy). All starting materials were purchased from Sigma-Aldrcih (St. Louis, MO, USA) and used without further purification. Experiments were performed in purified solvents.

N-(2-Benzoylphenyl)-5-fluoro-1H-indole-2-carboxamide (1). Ethyl-5-fluoroindole-2-carboxylate (6, $1.6 \mathrm{~g}, 7.6 \mathrm{mmol})$ was treated with 2-aminobenzophenone $(7,0.5 \mathrm{~g}, 2.5 \mathrm{mmol})$ in the presence of sodium ethoxide $(0.17 \mathrm{~g}, 2.5 \mathrm{mmol})$ and dimethylformamide (DMF, $10 \mathrm{~mL})$. The mixture was refluxed for $24 \mathrm{~h}$ at $160{ }^{\circ} \mathrm{C}$ and then filtered. DMF was removed by evaporation under reduced pressure and the residue was purified by column chromatography using cyclohexane/ethyl acetate $(85: 15)$ as eluent to afford the title compound as a yellow solid $(0.2 \mathrm{~g}, 11.6 \%)$. m.p. $237-238^{\circ} \mathrm{C} . R_{\mathrm{f}}=0.82\left(\mathrm{CHCl}_{3} / \mathrm{MeOH}\right.$, 96:4). ${ }^{1} \mathrm{H}-\mathrm{NMR}\left(\mathrm{CDCl}_{3}\right)$ : $\delta$ ppm 12.18 (br s, $1 \mathrm{H}, \mathrm{NHCO}$ ), 9.43 (br s, 1H, H-1 indole), 8.86 (d, $J=8.4 \mathrm{~Hz}, 1 \mathrm{H}, \mathrm{H}-3$ indole), 7.52-7.76 (m, 5H), 7.26-7.37 (m, 4H), 7.07-7.16 (m, 3H); ${ }^{13} \mathrm{C}-\mathrm{NMR}$ $\left(\mathrm{CDCl}_{3}\right): \delta$ ppm 199.49, 158.82, 139.88, 137.75, 133.77, 133.31, 132.32, 131.66, 131.47, 128.79, $127.98,127.39,121.61,121.27,120.07,113.19,112.83,111.87,111.74,105.79,105.48,102.97$, 102.89; IR (thin film): $v \mathrm{~cm}^{-1} 3298.28,2962.66,1666.50,1535.34,1446.61,1261.45,1095.57$, 1022.27, 798.53; MS (ESI, positive mode): $\mathrm{m} / \mathrm{z}[\mathrm{M}+\mathrm{H}]^{+} 359.11903\left(\mathrm{C}_{22} \mathrm{H}_{16} \mathrm{FN}_{2} \mathrm{O}_{2}\right.$ requires 359.11958); Anal. Calcd for $\mathrm{C}_{22} \mathrm{H}_{15} \mathrm{FN}_{2} \mathrm{O}_{2}$ : C, 73.73; H, 4.22; N, 7.82. Found: C, 73.65; H, 4.18, N, 7.91.

$\mathrm{N}$-(3-Benzoylphenyl)-5-fluoro-1H-indole-2-carboxamide (2). Ethyl-5-fluoroindole-2-carboxylate (6) $(1.0 \mathrm{~g}, 4.8 \mathrm{mmol})$ was treated with 3 -aminobenzophenone $(\mathbf{8}, 2.86 \mathrm{~g}, 14.4 \mathrm{mmol})$ in the presence of sodium ethoxide $(0.33 \mathrm{~g}, 4.8 \mathrm{mmol})$ and dimethylsulfoxide (DMSO, $10 \mathrm{~mL})$. The mixture of reaction was refluxed for $30 \mathrm{~h}$ at $190{ }^{\circ} \mathrm{C}$ and then filtered. DMSO was removed by evaporation under reduced pressure and the residue was purified by column chromatography using cyclohexane/ethyl acetate (80:20) as eluent to afford the title compound as a yellow solid $(0.1 \mathrm{~g}, 6 \%)$ : m.p. $249-250{ }^{\circ} \mathrm{C} . R_{\mathrm{f}}=0.83$ $\left(\mathrm{CHCl}_{3} / \mathrm{MeOH}, 94: 6\right) .{ }^{1} \mathrm{H}-\mathrm{NMR}\left(\mathrm{CDCl}_{3}\right): \delta \mathrm{ppm} 10.2$ (br s, $\left.1 \mathrm{H}, \mathrm{NHCO}\right), 9.23$ (br s, $1 \mathrm{H}, \mathrm{H}-1$ indole), $8.21\left(\mathrm{~s}, 1 \mathrm{H}, \mathrm{H}-3\right.$ indole), 7.9-8.1 (m, 3H), 7.7-7.8 (m, 4H), 7.5-7.6 (m, 3H), 7.05 (m, 2H); ${ }^{13} \mathrm{C}-\mathrm{NMR}$ $\left(\mathrm{CDCl}_{3}\right): \delta$ ppm 193.9, 166.5, 139.66, 137.85, 134.73, 136.52, 136.32, 132.28, 131.60, 130.54, 130.21, 
$129.42,124.56,121.13,127.04,122.0,113.14,112.78,111.66,111.21,105.49,104.78$; IR (thin film): $v \mathrm{~cm}^{-1} 3360.0,3290.56,1643.35,1589.34,1546.91,1435.04,1284.59,1215.15,850.25,803.39$; MS (ESI, positive mode): $\mathrm{m} / \mathrm{z}[\mathrm{M}+\mathrm{H}]^{+} 359.11903\left(\mathrm{C}_{22} \mathrm{H}_{16} \mathrm{FN}_{2} \mathrm{O}_{2}\right.$ requires 359.11958); Anal. Calcd for $\mathrm{C}_{22} \mathrm{H}_{15} \mathrm{FN}_{2} \mathrm{O}_{2}$ : C, 73.73; H, 4.22; N, 7.82. Found: C, 73.65; H, 4.18, N, 7.91.

$\mathrm{N}$-(4-Benzoylphenyl)-5-fluoro-1H-indole-2-carboxamide (3). Ethyl-5-fluoroindole-2-carboxylate (6) $(1.0 \mathrm{~g}, 4.8 \mathrm{mmol})$ was treated with 4-aminobenzophenone $(\mathbf{9}, 2.86 \mathrm{~g}, 14.4 \mathrm{mmol})$ in the presence of sodium ethoxide $(0.33 \mathrm{~g}, 4.8 \mathrm{mmol})$ and DMSO $(10 \mathrm{~mL})$. The mixture of reaction was refluxed for $6 \mathrm{~h}$ at $190{ }^{\circ} \mathrm{C}$ and then filtered. DMSO was removed by evaporation under reduced pressure and the residue was purified by column chromatography using cyclohexane/ethyl acetate (80:20) as eluent to afford the title compound as a yellow solid $(0.65 \mathrm{~g}, 37.5 \%)$. m.p. $249-250{ }^{\circ} \mathrm{C} . R_{\mathrm{f}}=0.67$ $\left(\mathrm{CHCl}_{3} / \mathrm{MeOH}, 94: 6\right) .{ }^{1} \mathrm{H}-\mathrm{NMR}\left(\mathrm{CDCl}_{3}\right): \delta$ ppm 12.33 (br s, $\left.1 \mathrm{H}, \mathrm{NHCO}\right), 9.25$ (br s, $1 \mathrm{H}, \mathrm{H}-1$ indole), $8.0\left(\mathrm{~s}, 1 \mathrm{H}, \mathrm{H}-3\right.$ indole), 7.75-7.86 (m, 4H), 7.3-7.6 (m, 5H), 7.0-7.18 ppm (m, 3H); ${ }^{13} \mathrm{C}-\mathrm{NMR}\left(\mathrm{CDCl}_{3}\right)$ : $\delta$ ppm 190.5,157.62, 140.32, 136.75, 133.73, 132.81, 132.32, 131.66, 131.47, 128.36, 127.08, 126.39, $121.81,121.22,120.47,113.0,112.63,111.93,110.89,105.23,104.88,102.54$; IR (thin film): $v \mathrm{~cm}^{-1}$ 3298.28, 2962.66, 1666.50, 1535.34, 1446.61, 1261.45, 1095.57, 1022.27, 798.53; MS (ESI, positive mode): $\mathrm{m} / \mathrm{z}[\mathrm{M}+\mathrm{H}]^{+} 359.11903\left(\mathrm{C}_{22} \mathrm{H}_{16} \mathrm{FN}_{2} \mathrm{O}_{2}\right.$ requires 359.11958); Anal. Calcd for $\mathrm{C}_{22} \mathrm{H}_{15} \mathrm{FN}_{2} \mathrm{O}_{2}$ : $\mathrm{C}$, 73.73; H, 4.22; N, 7.82. Found: C, 73.80; H, 4.27, N, 7.74.

5-Fluoro- $N$-[2-(4-methylbenzoyl)phenyl]-1H-indole-2-carboxamide (4). Ethyl-5-fluoroindole-2carboxylate $(\mathbf{6}, 0.33 \mathrm{~g}, 1.5 \mathrm{mmol})$ was treated with 2-aminobenzoyl-2-benzoic acid (10, $0.94 \mathrm{~g}$, $4.5 \mathrm{mmol})$ in the presence of sodium ethoxide $(0.1 \mathrm{~g}, 1.5 \mathrm{mmol})$ and DMF $(3 \mathrm{~mL})$. The mixture of reaction was refluxed for $20 \mathrm{~h}$ at $150{ }^{\circ} \mathrm{C}$ and then filtered. DMF was removed by evaporation under reduced pressure and the residue was purified by column chromatography using cyclohexane/ethylacetate $(85: 15)$ as eluent to afford the title compound as a yellow solid $(0.065 \mathrm{~g}$, 10\%). m.p. $233-234{ }^{\circ} \mathrm{C} . R_{\mathrm{f}}=0.77\left(\mathrm{CHCl}_{3} / \mathrm{MeOH}, 94: 6\right) .{ }^{1} \mathrm{H}-\mathrm{NMR}\left(\mathrm{CDCl}_{3}\right): \delta \mathrm{ppm} 12.1$ (br s, $1 \mathrm{H}$, NHCO), 9.4 (br s, 1H, H-1 indole), 8.85 (d, $J=7.8 \mathrm{~Hz}, 1 \mathrm{H}, \mathrm{H}-3$ indole), 7.6-7.7 (m, 4H), 7.25-7.41 $(\mathrm{m}, 5 \mathrm{H}), 7.06-7.16(\mathrm{~m}, 2 \mathrm{H}), 2.46(\mathrm{~s}, 3 \mathrm{H}) ;{ }^{13} \mathrm{C}-\mathrm{NMR}\left(\mathrm{CDCl}_{3}\right): \delta \mathrm{ppm} 199.1,158.75,142.45,139.62$, 134.97, 133.44, 133.06, 132.28, 131.69, 129.12, 128.06, 127.13, 127.04,122.0, 113.14, 112.78, 111.83 , 111.71, 105.79, 105.48, 102.91, 102.83, 20.65; IR (thin film): $v \mathrm{~cm}^{-1} 3313.71,2962.66,1670.35$, 1581.63, 1535.34, 1446.61, 1261.45, 1095.57, 1022.27, 803.39; MS (ESI, positive mode): $\mathrm{m} / \mathrm{z}[\mathrm{M}+\mathrm{H}]^{+}$ $373.13468\left(\mathrm{C}_{23} \mathrm{H}_{18} \mathrm{FN}_{2} \mathrm{O}_{2}\right.$ requires 373.13523); Anal. Calcd for $\mathrm{C}_{23} \mathrm{H}_{17} \mathrm{FN}_{2} \mathrm{O}_{2}: \mathrm{C}, 74.18 ; \mathrm{H}, 4.60 ; \mathrm{N}$, 7.52. Found: C, 74.24; H, 4.66, N, 7.43.

$\mathrm{N}$-[2-Benzoyl-4-chlorophenyl]-5-fluoro-1H-indole-2-carboxamide (5). Ethyl-5-fluoroindole-2carboxylate $(\mathbf{6}, 1.0 \mathrm{~g}, 4.8 \mathrm{mmol})$ was treated with 2-amino-5-chlorobenzophenone $(\mathbf{1 1}, 3.35 \mathrm{~g}$, $14.4 \mathrm{mmol})$ in the presence of sodium ethoxide $(0.33 \mathrm{~g}, 4.8 \mathrm{mmol})$ and DMSO $(8 \mathrm{~mL})$. The mixture of reaction was refluxed at $190{ }^{\circ} \mathrm{C}$ for $50 \mathrm{~h}$ and then filtered. DMSO was removed by evaporation under reduced pressure and the residue was purified by column chromatography using cyclohexane/ethylacetate $(90: 10)$ as eluent to afford the title compound as a yellow solid $(0.10 \mathrm{~g}$, 5.3\%). m.p. 202-203 ${ }^{\circ} \mathrm{C} . R_{\mathrm{f}}=0.86\left(\mathrm{CHCl}_{3} / \mathrm{MeOH}, 96: 4\right) .{ }^{1} \mathrm{H}-\mathrm{NMR}$ (DMSO-d6): $\delta$ ppm 11.87 (br s, 1H, NHCO), 10.8 (br s, 1H, H-1 indole), 7.76-7.84 (m, 4H), 7.4-7.67 (m, 6H), 7.22 (s, 1H), 7.11 (m, $1 \mathrm{H}) ;{ }^{13} \mathrm{C}-\mathrm{NMR}\left(\mathrm{CDCl}_{3}\right): \delta \mathrm{ppm} 194.34,159.93,137.18,135.64,134.29,133.58,133.49,132.88,132.3$, 
130.48, 130.03,129.12, 129.0, 126.71, 115.64, 115.12, 114.03, 113.71, 107.0, 106.48, 105.01, 104.89; IR (thin film): $v \mathrm{~cm}^{-1} 3448.72,3059.10,2962.66,1620.21,1465.90,1307.74,1257.59,1099.43$, 1026.13, 794.97; MS (ESI, positive mode): $\mathrm{m} / \mathrm{z}[\mathrm{M}+\mathrm{H}]^{+} 393.08006\left(\mathrm{C}_{23} \mathrm{H}_{15} \mathrm{ClFN}_{2} \mathrm{O}_{2}\right.$ requires 393.08061); Anal. Calcd for $\mathrm{C}_{23} \mathrm{H}_{14} \mathrm{ClFN}_{2} \mathrm{O}_{2}$ : C, 67.27; H, 3.95; N, 7.13. Found: C, 67.20; H, 3.89, N, 7.19.

\subsection{Animals and Treatments}

Forty eight adult male Wistar rats of two months of age, weighing around $180 \mathrm{~g}$, bred in the animal care centre of Faculty of Pharmacy, Al-Zaytoonah University, Amman, Jordan, were provided ad libitum access only to tap water throughout the experiments. Rats were maintained in a $12 \mathrm{~h}$ light-dark cycle under constant humidity and $\left(22 \pm 2{ }^{\circ} \mathrm{C}\right)$. All experiments were performed in accordance with the Guidelines for Animal Welfare Committee of Al-Zaytoonah University.

\subsection{Triton model of Hyperlipidemia}

Triton WR-1339 was dissolved in (DMSO) and administered intraperitoneally to the rats (300 mg/kg body weight) in order to induce hyperlipidemia.

\subsection{Pharmacological Experimental Design}

Overnight fasted rats were randomly divided into six groups of eight animals each. The first group, serving as control group (CG) received an intraperitoneal administration of normal saline; the second hyperlipidemic group (HG) received an intraperitoneal injection of Triton 4\% DMSO (in distilled water). In the third group compound 1 was intraperitoneally injected with Triton, followed by an intragastric administration of compound 1 (15 mg/kg body weight) dissolved in 4\% DMSO; in the rats of the fourth group compound 2 were also intraperitoneally injected with Triton, followed by an intragastric administration of compound $2(15 \mathrm{mg} / \mathrm{kg}$ body weight) dissolved in 4\% DMSO. In the fifth group compound 3 were intraperitoneally injected with Triton, followed by an intragastric administration of compound 3 (15 mg/kg body weight) dissolved in 4\% DMSO.The last group (BF) was also intraperitoneally injected with Triton and intragastrically treated with bezafibrate $(100 \mathrm{mg} / \mathrm{kg}$ body weight) dissolved in 4\% DMSO. After $12 \mathrm{~h}$ of treatments, animals were anaesthetized with diethyl ether and blood was collected. The blood samples were immediately centrifuged $(3,000 \mathrm{rpm}$ for $10 \mathrm{~min}$ ) and the plasma was used for lipid analysis by an enzymatic method with an automatic analyzer (Model Erba XL-300, Germany, Mannheim, Germany).

\subsection{Statistical Analysis}

Results were expressed as mean values and standard deviations. Data obtained were analyzed using the Student's t-test, and differences with $p<0.05$ were considered statistically significant.

\section{Conclusions}

In conclusion, 5-fluoro- $1 H$-indole-2-carboxamide derivatives 2 and $\mathbf{3}$ improved the lipid profile in Triton-induced hyperlipidemic rats. The results of this study are highly promising, but further studies 
are required to elucidate the exact mechanism of action as lipid-lowering agents of these novel compounds.

\section{References}

1. McKenney, J.M. Dyslipiemias. In Applied Therapeutics, 7th ed.; Koda-Kimble, M.A., Young, L.Y., Eds.; Lippincott Williams and Wilkins: Philadelphia, PA, USA, 2001; pp. 11:1-11:43.

2. Libby, P.; Schoenbeck, U.; Mach, F.; Selwyn, A.P.; Ganz, P. Current concepts in cardiovascular pathology: The role of LDL cholesterol in plaque rupture and stabilization. Am. J. Med. 1998, 104, 18S-27S.

3. Martin, M.J.; Hulley, S.B.; Browner, W.S.; Kuller, L.H.; Wentworth, D. Serum cholesterol, blood pressure, and mortality: implications from a cohort of 361,662 men. Lancet 1986, 2, 933-936.

4. West, K.M.; Ahuja, M.S.; Bennet, P.H. The role of circulating glucose and triglyceride concentrations and their interactions with other "risk factors" as determinants of arterial disease in nine diabetic population samples from the WHO multinational study. Diabetes Care 1983, 6, 361-369.

5. Otway, S.; Robinson, D.S. The effect of the nonionic detergent (Triton) on the removal of triglyceride fatty acids from the blood of the rats. J. Physiol. 1967, 190, 309-319.

6. Schurr, P.E.; Schultz, J.R.; Parkinson T.M. Triton-induced hyperlipidemia in rats as an animal model for screening hypolipidemic drugs. Lipids 1972, 7, 69-74.

7. Hayashi, H.; Niinobe, S.; Matsumoto, Y.; Suga, T. Effects of Triton WR-1339 on lipoprotein lipolytic activity and lipid content of rat liver lysosomes. J. Biochem. 1981, 89, 573-579.

8. Frick, M.H.; Elo, O.; Haapa, K.; Heinonen, O.P.; Heinsalmi, P.; Helo, P.; Huttunen, J.K.; Kaitaniemi, P.; Koskinen, P.; Manninen, V.; Mäenpää, H.; Mälkönen, M.; Mänttäri, M.; Norola, S.; Pasternack, A.; Pikkarainen, J.; Romo, M.; Sjöblom, T.; Nikkilä, E.A. Helsinki Heart Study: primary-prevention trial with gemfibrozil in middle-aged men with dyslipidemia. Safety of treatment, changes in risk factors, and incidence of coronary heart disease. New Engl. J. Med. 1987, 317, 1237-1245.

9. Rubins, H.B.; Robins, S.J.; Collins, D.; Fye, C.L.; Anderson, J.W.; Elam, M.B.; Faas, F.H.; Linares, E.; Schaefer, E.J.; Schectman, G.; Wilt, T.J.; Wittes, J. Gemfibrozil for the secondary prevention of coronary heart disease in men with low levels of high-density lipoprotein cholesterol. Veterans Affairs High-Density Lipoprotein Cholesterol Intervention Trial Study Group. New Engl. J. Med. 1999, 341, 410-418.

10. Schoonjans, K.; Staels, B.; Auwerx, J. Role of the peroxisome proliferator-activated receptor (PPAR) in mediating the effects of fibrates and fatty acids on gene expression. J. Lipid Res. 1996, 37, 907-925.

11. Al-Qirim, T.; Shahwan, M.; Shattat, G.; Al-Hiari, Y.; Abu Sheikha, G.; Zaidi, S. Pharmacological evaluation of novel indole-2-carboxamides as potent lipid-lowering agents in Triton-WR1339-induced hyperlipidemic rats. Z. Naturforsch. 2009, 64c, 619-625.

12. Bosies, E.; Heerdt, R.; Kuknle, H.F.; Schmidt, F.H.; Stach, H. Hypoglycemically and hypolipidemically active derivatives of phenylalkane carboxylic acids. U.S. Patent 4,113,871, 4 August 1976. 
13. Dasseux, J.; Oniciu, C.D. Ketone compounds and compositions for cholesterol management and related uses. U.S. Patent 20,100,137,444, 26 June 2009.

14. Kopin, A.S.; Carey, M.; Wang, D. Methods of altering intestinal motility and absorption of hydrophobic compounds through the use of agonists and/or antagonists of the cholecystokinin-1 receptor. U.S. Patent 224,869, 13 September 2005.

15. Sher, P.M.; Ellsworth, B.A. Triglyceride and triglyceride-like prodrugs of glycogen phosphorylase inhibiting compounds. U.S. Patent 7098235, 13 November 2003.

16. Robichaud, L.J.; Stewart, S.F.; Adolphson, R.L. CI-922 - a novel, potent antiallergic compound. I. Inhibition of mediator release in vitro. Int. J. Immunopharmacol. 1987, 19, 41-49.

17. Olgen, S.; Coban, T. Synthesis and antioxidant properties of novel N-substituted indole-2carboxamide and indole-3-acetamide derivatives. Arch. Pharm. 2002, 335, 331-338.

18. Liu, G.; Zhang, Z.; Luo, X.; Shen, J.; Liu, H.; Shen, X.; Chen, K.; Jiang, H. Inhibitory mode of indole-2-carboxamide derivatives against HLGPa: Molecular docking and 3D-QSAR analyses. Bioorg. Med. Chem. 2004, 15, 4147-4157.

19. Lauk, L.; Galati, E.M.; Forestieri, A.M.; Kirjavainen, S.; Trovato, A. Mucuma pruriens infusion lowers cholesterol and total lipid plasma levels in the rats. Phytother. Res. 1989, 3, 263-264.

20. Khanna, A.K.; Chauder, R.; Chandan, S.; Srivastava, A.K.; Kapoor, N.K. Hypolipidemic activity of Achyranthus aspera linn in normal and triton induces htperlipemic rats. Indian J. Exp. Biol. 1992, 30, 128-130.

21. Yamamoto, K.; Byrne, R.; Edelstein, C.; Shen, B.; Scanu, A.M. In vitro effect of Triton WR-1339 on canine plasma high density lipoproteins. J. Lipid Res. 1984, 25, 770-779.

22. Otway, S.; Robinson, D.S. The effect of the nonionic detergent (Triton) on the removal of triglyceride fatty acids from the blood of the rats. J. Physiol. 1967, 190, 309-319.

23. Campillo, J.E.; Torres, M.D.; Dominguez, E.; Romero, A.; P'erez, C. Ficus carica leaf administration reduces hypertrygliceridaemia in streptozotocin diabetic rats. Diabetologia 1994, 37, A213.

24. P'erez, C.; Canal, J.R.; Campello, J.E.; Adelaida, R.; Torres, M.D. Hypotriglyceridaemic activity of Ficus carica leaves in experimental hypertriglyceridaemic rats. Phytother. Res. 1999, 13, 188-191.

25. Malloy, M.J.; Kan, J.P. Medical management of hyperlipidemic states. Ad. Int. Med 1994, 39, 603-631.

26. Anila, L.; Vijayalakshmi, N.R. Flavonoids from Emblica officinalis and Mangifera indicaeffectiveness for dyslipidemia. J. Ethnopharmacol. 2002, 79, 81-87.

27. Staels, B.; Dallongville, J.; Auwerx, J.; Schoonjans, K.; Leitersdorf, E.; Fruchart, J.C. Mechanism of action of fibrates on lipid and lipoprotein metabolism. Circulation 1998, 98, 2088-2093.

Sample Availability: Samples of the compounds are available from the authors.

(C) 2010 by the authors; licensee MDPI, Basel, Switzerland. This article is an open access article distributed under the terms and conditions of the Creative Commons Attribution license (http://creativecommons.org/licenses/by/3.0/). 